\title{
Tap into Students' Metacognitive Strategies Report via the Internet-Mediated Contextualized English for Domestic Tourism Lessons (InConMedt)
}

\author{
Malinee Phaiboonnugulkij \\ English Program Faculty of Humanities and Social Sciences \\ Nakhon Ratchasima Rajabhat University, 340 Suranarai Road Mueang District Nakhon Ratchasima, Thailand \\ E-mail: malineerabbit@hotmail.com
}

Received: 20-09-2015

Published: 01-03-2016
Accepted: 26-12-2015

doi:10.7575/aiac.ijalel.v.5n.2p.171
Advance Access Published: January 2016

URL: http://dx.doi.org/10.7575/aiac.ijalel.v.5n.2p.171

This research is funded by the Research Institute Nakhon Ratchasima Rajabhat University.

\begin{abstract}
The objectives of this paper were to compare total and individual metacognitive strategies by four groups of university students from different majors in five different tourism situational lessons. The total of 34 students participated in this study, and they were categorized into four groups based on their major of study and English proficiency level. The research instruments were a web-based speaking test in English for Tourism (WBST-EFT), a strategy coding scheme and the Internet-mediated contextualized English for Domestic Tourism lessons (InConMedt). Mixed methods of quantitative and qualitative approaches were employed in the present study. The quantitative analysis included Kruskal Wallis, Mann-Whitney U test as well as Chi-square, mean rank, frequency and percentages. Qualitative content analysis from the verbal reports in the stimulated recall session on metacognitive strategies was employed in this study. The findings showed that four groups significantly and differently employed total metacognitive strategies in five lessons, $\square^{2}(3, N=34)=10.00, p=.01$. The significant difference was evident in the use of individual metacognitive strategies including goal setting and planning of the groups and in a particular lesson. The insights from the verbal report content analysis revealed significant information on how the high proficiency group effectively employed their metacognitive strategy in their speaking performances; whereas the information from the low proficiency group also shed more light in the instructional approach on how to train these students to improve their speaking ability using effective strategies.
\end{abstract}

Keywords: Metacognitive strategies, Online speaking lesson, English for Tourism

\section{Introduction}

Metacognitive strategies function as an integral part in English language learning, particularly in language for specific purposes (LSP) area. These strategies are employed to relate English language knowledge and specific area background knowledge in both language formulation and production (Douglas, 2000). Metacognitive strategies entail planning for and monitoring or evaluating the success of a learning activity (O'Malley \& Chamot, 1990). A number of researches claim that metacognitive strategies had positive effects in English language learning and teaching these strategies could motivate students to learn the language effectively (Lam, 2009, 2010; Hong-Nam \& Leavell, 2006; Cabaysa \& Baetiong, 2010). Moreover, metacognitive strategies are considered as a foundation for students to study at their own pace, allowing them to control over their learning that can help students to improve their performances, and in turn facilitate them to use English language effectively (Liu \& Feng, 2011).

Additionally, this significant role of metacognitive strategies in English language learning is considered important, specifically in LSP area that has prominent feature of contextualized language use in a particular setting and scenario. The way learners employ these strategies in English for Domestic Tourism course is focused this study. Previous studies show that a utilization of metacognitive strategies varies with learners' proficiency level (Cabasaya \& Baetiong, 2010; Swain, Huang, Barkaoui, Brooks, \& Lapkin, 2009) and other factors; therefore, metacognitive strategies are investigated in the present study with university students from different majors of study. Moreover, English for Domestic Tourism is purposively selected in this study from its importance as an income generator to Thailand. Recent reports from World Travel and Tourism Council show a contribution of Travel and Tourism to Thai economy of 2,345.1 billion Thai Baht, 19.3 per cent of total gross domestic product (GDP) in 2014, and the expectation to increase at 3.2 per cent in 2015 . Focusing on the employment, this industry alone took up 14.1 per cent of all total occupations in Thailand in 2014 and the expectation of a rise 1 more per cent in 2015 (The Authority of World Travel and Tourism, 2015, p.1). English for Domestic tourism course is thus offered in a large number of educational institutions, including Nakhon Ratchasima Rajabhat University, a comprehensive university with more than 23,000 students. The main goal of English for Domestic course is to produce English speaking tourism staff to work in this industry. Students are thus required to pass the course with sufficient English proficiency, particularly in their speaking skill so that they can be capable of using English to deal with foreign tourists. 
Learning English beyond classroom wall with authentic materials is viewed as effective learning environment where students have a chance to actually use English language and are engaged in the social and actual communications, especially in LSP content area course (Tarnopolsky, 2013). Technology integrated language learning, an online platform, is implemented in the present study to achieve this goal. The advantages of online technology in language instruction are in providing an opportunity for students to interact with their peers, self-practice, co-create knowledge and share experience at their preferable place and time through collaborative learning. This online-blended classroom corresponds with social constructivism theory that students do need to internalize the knowledge by themselves to actually acquire the knowledge (Ismaili, 2014). Social constructivism with Internet technology is thus integrated into this study as an effective instructional tool to deal with such a large number of students, and ultimately to provide students with a chance to practice and engage them to learn the language in a real world context. Social constructivism explains how learning can be fostered effectively through interactive pedagogical practices. The focus is on the learners as an "active constructors of their own learning environment" (Mitchell \&Myles, 1988, p.162 cited in Phaiboonnugulkij, 2015).

Although metacognitive strategies have a main function in English language learning, the way they are utilized in online-integrated English language learning is considered new (Liu \& Feng, 2011), especially when they are used in LSP subject area in English for Tourism context underpinned by the social constructivism theory. Owing to their essential role and specific feature of English used in specific Tourism areas with the innovative modality together with learners' characteristics, an investigation into how learners from different fields of studies employ their metacognitive strategies in this Tourism online learning is the emphasis of this study. The findings can also shed more light into LSP fields on how students employ their higher order thinking in tourism context, especially in Thailand at a university level in this online modality. This study thus aimed to compare the use of total and individual metacognitive strategies via the 5 Internet-mediated contextualized English for Domestic Tourism lessons between high- and low-proficiency groups and business English and tourism industry majored students.

\section{Literature review}

\subsection{Language for specific purposes ability and metacognitive strategies}

LSP ability from Douglas (2000)'s framework has one of the key component, strategic competent which espouses metacognitive strategies, higher order thinking and communication strategies. From Douglas' definition, strategic competent functions as a mediator relating language knowledge and specific background knowledge in language formulation and production processes. LSP ability is thus a result from that interactional process between two major components. Strategic competent includes discourse assessment, communicative goal setting, linguistic planning, and control of linguistic execution. (Phaiboonnugulkij \& Prapphal, 2011, 2013). Similarly, O’Malley and Chamot (1990) defined metacognitive as "higher order executive skills that may entail planning for, monitoring or evaluating the success of a learning activity" (p.44).

In the present study, metacognitive strategies are defined as the higher order conscious thoughts that the students employed in their learning for speaking in the lesson. Metacognitive strategies act as mediator to related English language knowledge and tourism related content knowledge to formulate and produce the language when students study English for Tourism. Metacognitive strategies are made up of three main sub-strategies: assessment, goal setting, and planning.

\subsection{Metacognitive strategies in English language oral ability}

Metacognitive strategies are investigated in English language learning context in different aspects including relationship between the use of metacognitive strategies and the proficiency level, the use of metacognitive strategies and gender and nationality. However, the results are still varied. Effects of teaching metacognitive strategies on oral communication in different variables are also explored: target strategy, proficiency level and, task effectiveness. The findings from these previous studies showed positive effects of the metacognitive instruction on oral communication ability.

The effects of teaching metacognitive strategies on oral group discussion were examined in ESL group by Lam (2009), using multi-method approach with 40 ESL Hong Kong University students for 20 week. Metacognitive strategies in this study subsumed seven types: problem identification, planning content, planning language, evaluation, asking for help, giving help and positive-self talk. The findings showed the E class (a treatment class) had significant and higher posttest scores in both English proficiency and task effectiveness than those of the C class (a comparison class), indicating that strategy instruction tended to lead to the improvement of these two aspects, particularly on the higher score of the task effectiveness than the language proficiency. It was also found that strategy instructions had relative effect on the target strategies of $\mathrm{E}$ over $\mathrm{C}$ class in six of the seven strategies. From the increased score in both English language proficiency and task effectiveness, it may be due to the explicit instruction of teaching metacognitive strategies that could raise students' awareness of using these strategies in their oral discussion tasks.

Similarly, effects of teaching metacognitive strategies on target and non-target strategies in the ESL oral classroom were later conducted in 2010 by Lam. The participants were 40 secondary two students who had studied English for seven years in Hong Kong. They were separated into two classes, a treatment class (E class) and a comparison class (C class). The findings showed no effects from teaching metacognitive strategies in the treatment class on the use of nontarget strategies in a group discussion task. However, the two classes gradually increased in the reporting of metacognitive strategies from 15.6 per cent to 35.3 per cent in the treatment class and from 22.2 to 33.3 per cent for a comparison class. In other words, teaching metacognitive strategies brought about a general increase in the target 
strategies of both classes. It was concluded that metacognitive strategies instruction had differential and desirable effects on the target strategies in a predictable way which supported the value of strategy instruction. The purpose of teaching the metacognitive strategies should raise general strategic awareness by directing learners' attentions to their own strategies and the ones that were found to be effective in the treatment group of this study.

Likewise, Hong-Nam \& Leavell (2006) explored the language learning strategy used of ESL students in integrated skills intensive English program (IEP) focusing on the relationship between language strategy used and the target language proficiency. The total of 55 ESL students participated in this study and they were classified into three groups: beginning (11), intermediate (30) and advanced (14). Among the five strategies, metacognitive (M=3.66) was the most favored strategy by the participants. Regarding the language learning strategies used and level of target language proficiency, the results revealed that the intermediate learners employed more strategies than their counterparts. However, metacognitive strategies were used by the beginners and intermediate groups whereas the advanced level preferred social strategies most. The findings of proficiency level corresponded with previous studies that used the metacognitive strategies and were associated with proficiency level (Cabaysa \& Baetiong, 2010; Ma, 2009). Cabaysa \& Baetiong (2010) conducted a comparative analysis on the use of metacognitive, social/affective and compensation strategies between intermediate and novice students. The findings showed that metacognitive strategies were the most frequently reported by the two groups. There was a significant difference in the frequency of the metacognitive strategies between the two groups (novice $=75$, intermediate $=165$ ) in that the intermediate reported more than twice as many metacognitive strategies as the novice group. The most frequently report sub-metacognitive strategy was planning, as it was considered as a significant part of the speech production process. This sub-strategy was employed to enable the learners to intentionally and consciously focus attention on a task, engage in the planning and monitor their output, while also lead them to assess their performances (Cabaysa \& Baetiong, 2010 cited in Phaiboonnugulkij \& Prapphal, 2013). Similarly, Ma (2009) found a significantly and closely correlated relationship between proficiency levels and the use of speaking strategies. High-proficiency students reported a greater use of language strategies than those with low proficiency levels.

\subsection{Metacognitive strategies in a technology-integrated learning}

Metacognitive strategies have been investigated widely in a large number of areas, particularly their effects on English language learning achievements. However, an investigation into the use of metacognitive strategies in online learning modality is considered scant and viewed as a new area of study (Liu \& Feng, 2011). Most of the studies compare the use of metacognitive strategies across different proficiency groups, task-types and test-achievement scores. The results from some studies reveal that metacognitive strategies used in computer-mediated English language learning were found to be favored by the high-proficiency English language learners (Liu and Feng, 2011). Although metacognitive strategies are the most frequently reported, there are no differences between the use of these strategies across different proficiency groups in some studies (Swain, Huang, Barkaoui, Brooks, \& Lapkin, 2009).

Metacognitive strategies are investigated in a technology-integrated English language learning environment in a study of Liu and Feng (2011). The authors investigated the use of metacognitive strategies in an online-learning of 98 first year students from Beijing University from 13 different majors in China. The study was conducted due to a new requirement from Higher Education Department of Education Ministry, to enhance English language use with the students since 2004. Computer- and classroom-based English teaching model was founded to meet that requirement. In this learning environment, students had a chance to learn the language by themselves using a computer, to discuss among their peers and self-test their performance. It was proven that students' speaking and listening abilities through this learning modality were improved effectively since they won the first prize at the national English debate contest in 2007. The results showed a significant difference in the use of metacognitive strategies in the final examination's result between the high- and low-ability students at the .05 level, in which the high group reported more strategies than that of the low group. It was concluded in this study that students who were better aware of the use of their metacognitive strategies showed a greater engagement in learning and had better self-learning ability and test-achievement. Similar to the Wen (2006)'s study, metacognitive strategies should be trained to students to improve their learning performances, particularly with the low ability group. Metacognitive strategies are the foundation of self-learning abilities and this self-learning can help students to improve their test performances and in turn facilitate them to use language effectively, thus, it is a must to train students to use this higher-order of thinking.

However, use of metacognitive strategies was not different across proficiency groups in a study of Swain et al. (2009). This study explored the use of metacognitive strategies in TOEFL iBT, an internet version in four different proficiency groups totaling 40 participants: graduates intermediate (a), undergraduates advanced (b) and undergraduates intermediate (c). In this study, use of metacognitive strategies was investigated in speaking section across the three task-types: 1) independent, 2) integrated reading, listening and speaking and 3) integrated listening and speaking. The findings showed that metacognitive strategies were the most frequently reported by all participants at 33.42 per cent. However, there was no significant difference in the use of metacognitive strategies across these groups. Furthermore, participants employed similar strategies within the integrated tasks than the independent task. They also used a wider range of strategies in the integrated task than in the independent one. It was concluded that relationships between choice of strategy use and proficiency levels relied on participants' characteristics, tasks and context.

\subsection{Social constructivism and technology-integrated learning}

Social constructivism approach conceptualizes learning that is "constructed" by learners. Learning thus occurs through active construction. Vygotsky, the founder of social constructivism, viewed that learners' construction of knowledge is the result of the interaction in social environments (Vygotsky, 1978); ideas and knowledge are thus constructed through 
communication. An individual cognitive system is a result of communication through social groups (Vygotsky, 1978, 1987). Knowledge acquisition subsumes two kinds of activities: intercommunication, or between people and later intracommunication within ourselves (Wilson, 1999). Individuals acquire knowledge through collaborative group work in a dialectical environment. Intracommunication is a process of self-reflection on different things (Luksaneeyanawin, 2008). Intracommunication functions importantly in language acquisition since language learning involves learning word meaning and internalizing the structure of language (Schcolnik, Kol \& Abarbanel, 2006). Another notion under social constructivism is the zone of proximal development (ZDP): the actual developmental level, determined by what learner can do alone, and the potential level of development, established by observing what the learner can do when supported by teachers or more advanced peers.

The English language environment that encompasses the notion of social constructivism at present is the use of technology assisted language learning (TALL), including online learning and corresponds with social constructivism theory that students need to internalize the knowledge by themselves to actually acquire the knowledge (Ismaili, 2014). Students learn both language and culture from their peers around the world which encourages them to understand and look at learning from different perspectives, thus, in turn could increase their metacognitive (Yang \& Wilson, 2006). Authentic or "situated learning" is found in online learning (McMahon, 1997). Adding to this significance, using Elearning under social constructivism is found to foster students' English language skills and increase interactive learning process in collaborative learning. The online environment supports a more reflective of metacognitive and promotes real time communication in collaborative learning (Barhoumi \& Hamza kabli, 2013; Churcher, Downs, \& Tewksbury, 2014). McMahon (1997) suggested that strengths of signals and accessibility of the Internet should be considered, but this type of learning may not be appropriate in the course that required learners' involvement in physical environment practice (Phaiboonnugulkij, 2015).

\section{Methodology}

\subsection{Participants}

The participants in this study consisted of 34 second year tourism industry and business English majored students taking 2017363 English for Domestic Tourism in the first semester of the academic year 2014. They passed 2017362 English for Local Tourism, a pre-requisite course, English for Domestic Tourism. They were classified into four groups based on their proficiency level and major of study using a web-based speaking test in English for Tourism (WBST-EFT) (Phaiboonnugulkij \& Prapphal, 2011, 2013). Students with the means ranged from band 2.20 and 2.45 were assigned into a high- proficiency group, whereas those with means ranged from band 1.20 to 1.60 were in a low-proficiency group (Phibonnugulkij, 2015). This was resulted in four groups of students, 15 high-proficiency tourism industry students (group1), 15 low-proficiency tourism industry students (group2), 2 high-proficiency business English students (group3)and 2 low-proficiency business English students (group 4). The reason that group 3 and 4 contained only 2 participants was due to the minimum number of students from this major. There were firstly 8 of them, but later 4 dropped out.

\subsection{Instrumentation}

The instrumentation in this study consisted of three instruments: strategy coding scheme, web-based speaking test in English for Tourism (WBST-EFT) and the rating scale and the Internet-mediated contextualized English for Domestic Tourism lessons (InConMedt). Followings are details of the instrumentation.

\subsubsection{Strategy coding scheme}

Strategy coding scheme subsumes metacognitive strategies from Douglas (2000)'s LSP ability notion and O’Malley \& Chamot (1990)'s language learning strategies. After the definitions of metacognitive strategies were drafted, questions in the stimulated recall interview were created following Swain et al. (2009)'s questions on strategy interviews. These questions were used to elicit types and frequency of reported metacognitive strategies in five online lessons. All of the instruments were validated by three experts in the field using item-objective congruence table (IOC). The item values ranged from 0.75 to 1 ; revisions of all instruments were made before and after the pilot study. Metacognitive strategies were then transcribed and categorized by two coders using the coding scheme. Coder training was conducted before the main study to ensure consistency coding from two coders, one was the researcher and another was the English for Local and Domestic Tourism lecturer at NRRU, holding an M.A. in English language studies with 34 years of teaching experience.

\subsubsection{Web-based speaking test in English for Tourism (WBST-EFT) and the rating scale}

A web-based speaking test in English for Tourism (WBST-EFT) is an online achievement test in English for Domestic course and made up of six test tasks in total. Only five are pertinent to the InConMedd and were selected for this study. Students were given welcoming speech, presenting Buddha images, tour itinerary, the Emerald Buddha Temple and Grand Palace, and about giving suggestions to the tourists. The test is delivered via Facebook at NRRU laboratory and removed right after the students have completed it for the security of test item. Students attempted the test by speaking through the microphone and their speech responses were audio recorded. Students then submitted their test audio file to the message device and all of the responses were rated later by the two raters for validity and reliability of the test scores. This online test posts high quality of content and construct validity at IOC value of one and inter-rater reliability value from Pearson correlation coefficient is at .94, showing high reliability of the test (Phaiboonnugulkij \& Prapphal, 2011, 2013; Phaiboonnugulkij, 2015). 
The analytical rating scale is used in this study from the appropriateness to the lessons from InConMedt, and the criteria are range and accuracy in linguistics components and content, and fluency of speech production. The rating scale consists of three components: content knowledge, accuracy in vocabulary and grammatical structure and fluency of speech performances. Each component is made up of five ability bands, starting from band level 0 (a very poor user), 1(a beginner), 2 (a fair user), 3 (a good user) to 4 (a very good user). The ability band is from the summation of the average score from two raters. Rater training was conducted before the pilot study to ensure the reliability and consistency in scoring methods in the main study (Phaiboonnugulkij \& Prapphal, 2011 \&2013; Phaiboonnugulkij, 2015).

\subsubsection{The Internet-mediated contextualized English for Domestic Tourism lessons (InConMedt)}

The Internet-mediated contextualized English for Domestic Tourism lesson (InConMedt) is an online lesson in 2017363 English for Domestic Course at NRRU and offered in the first semester of every academic year. It is a compulsory for tourism industry and business English majored students (Curriculum for Bachelor of Arts in English and Tourism Industry, 2008).

The final version of InConMedt is made up of five lessons from English for Domestic Tourism course: giving welcoming speech (lesson 1), presenting Buddha images (lesson 2), presenting tour itinerary (lesson 3), presenting the Emerald Buddha Temple and Grand Palace (lesson 4), and giving suggestions to the tourists (lesson 5). These online lessons last 12 weeks and they are selected by subject specialist informants and these lessons are the highlight of course. Learning procedures in this online lesson underpin social constructivism theory of Vygotsky (1987) and Churcher et al. (2014) with the integration of the interface design from Fulcher (2003) and Winke (2014). The lessons are converted into online version and posted on Facebook, a social media that is currently used by all of the students in the course so that no students would be left behind without mentor and guidance from the lecturer, and the lessons are made up of different media including video and audio clip, PowerPoint presentation, motion picture and useful links.

In this hybrid learning environment, students are firstly required to self-study all online lessons and then come to class to reflect and share their learning among their peers and lecturer. The InConMedt encompasses three main stages in chronological orders: intercommunication, intracommunication and didactic learning. All the three main stages are recursive depending on students' needs in a particular lesson. In the first stage: intercommunication, an elicitation to a collaborative learning by using English language, students are required to work collaboratively in groups such as through online discussion based on the tasks of each lesson. It is followed by intracommunication that aims to encourage students to self-study both the English language use and the content in each lesson. They are required to reflect on their understanding through the individual tasks. They will receive lecturer's comment through their individual "message box". Finally, students participate in didactic learning to engage them in the lesson, students are provided with scenarios related to tourism contexts, tasks and projects to work on. They are required to find out more about the useful English expressions, specific content from the online lesson and present them in front of the class for authentic purposes of being a tour guide in front of a group of tourists.

Similar to previous instruments, InConMedt was validated by three experts in the field using IOC table, and the values range from .75 to 1 . All the comments and suggestions from the experts are used in the revision stage of this instrument. It was tried out with a group of sample before being used in the main study (Phaiboonnugulkij, 2015).

\subsection{Data collection procedures}

The data were collected in the following procedures.

First, students self-studied each online lesson before attending the class. Then they were informed that they were required to report their learning from each online lesson. Their responses would be recorded for data transcription. They were also informed that this method would not affect their grade and they should report how they learn with true information. They may take notes on how and what they have studied in the online lesson.

Next, at the end of each lesson, they were required to participate in stimulated recall interview sessions to elicit their use of metacognitive strategies. In this session, they were asked to think about what they were thinking before, while and after studying the online lesson. They may use their notes and their audio files, project works and assignments as stimulus to recall their thinking processes. Coders' intervention was kept minimum based on suggestion from Gass \& Mackey (2007) to get the valid data from students.

Finally, all the recorded responses were transcribed and counted on both frequency and type of metacognitive strategies used in the four groups of students by the two coders using coding scheme. Their verbal reports on metacognitive strategies were categorized and grouped by two coders following the definitions of individual metacognitive strategies. Their responses on individual metacognitive strategies were compared among four groups of students in five lessons in the content analysis part.

\subsection{Data analysis procedures}

To achieve two objectives, Chi-square was used to investigate the differences on the total metacognitive strategies between the two proficiency groups and their majors. Kruskal-Wallis Test was used to indicate the highest and lowest ranks. This includes Mann-Whitney $U$ test, descriptive statistics, mean rank and percentages. Qualitative content analysis from stimulated recall interviews were analyzed to see how each proficiency group and major used the metacognitive strategies in the course. 
4. Results and discussions

4.1 Total use of metacognitive strategies via the InConMedt among four groups of students in five tourism lessons

4.1.1 Total use of metacognitive strategies by four groups of students in five lessons

Table 4.1 Mean rank in the total use of metacognitive strategies by four groups of students in five lessons

\begin{tabular}{|c|c|c|c|}
\hline Lessons & Groups of students & Strategies & Mean rank \\
\hline \multirow{5}{*}{ Lesson 1} & High-tourism $(\mathrm{N}=15)$ & 3 & 10.67 \\
\hline & Low-tourism $(\mathrm{N}=15)$ & 3 & 8.17 \\
\hline & High-business English $(\mathrm{N}=2)$ & 3 & 4.83 \\
\hline & Low-business English $(\mathrm{N}=2)$ & 3 & 2.33 \\
\hline & Total $(\mathrm{N}=34)$ & 12 & \\
\hline \multirow{5}{*}{ Lesson 2} & High-tourism $(\mathrm{N}=15)$ & 3 & 10.33 \\
\hline & Low-tourism $(\mathrm{N}=15)$ & 3 & 8.67 \\
\hline & High-business English $(\mathrm{N}=2)$ & 3 & 4.67 \\
\hline & Low-business English $(\mathrm{N}=2)$ & 3 & 2.33 \\
\hline & Total $(\mathrm{N}=34)$ & 12 & \\
\hline \multirow{5}{*}{ Lesson 3} & High-tourism $(\mathrm{N}=15)$ & 3 & 9.83 \\
\hline & Low-tourism $(\mathrm{N}=15)$ & 3 & 9.17 \\
\hline & High-business English $(\mathrm{N}=2)$ & 3 & 4.67 \\
\hline & Low-business English $(\mathrm{N}=2)$ & 3 & 2.33 \\
\hline & Total $(\mathrm{N}=34)$ & 12 & \\
\hline \multirow{5}{*}{ Lesson 4} & High-tourism $(\mathrm{N}=15)$ & 3 & 9.33 \\
\hline & Low-tourism $(\mathrm{N}=15)$ & 3 & 9.67 \\
\hline & High-business English $(\mathrm{N}=2)$ & 3 & 5.00 \\
\hline & Low-business English $(\mathrm{N}=2)$ & 3 & 2.00 \\
\hline & Total $(\mathrm{N}=34)$ & 12 & \\
\hline \multirow{5}{*}{ Lesson 5} & High-tourism $(\mathrm{N}=15)$ & 3 & 11.00 \\
\hline & Low-tourism $(\mathrm{N}=15)$ & 3 & 7.67 \\
\hline & High-business English $(\mathrm{N}=2)$ & 3 & 5.33 \\
\hline & Low-business English $(\mathrm{N}=2)$ & 3 & 2.00 \\
\hline & Total $(\mathrm{N}=34)$ & 12 & \\
\hline \multirow{5}{*}{ Total 5 lessons } & High-tourism $(\mathrm{N}=15)$ & 3 & 10.67 \\
\hline & Low-tourism $(\mathrm{N}=15)$ & 3 & 8.33 \\
\hline & High-business English $(\mathrm{N}=2)$ & 3 & 5.00 \\
\hline & Low-business English $(\mathrm{N}=2)$ & 3 & 2.00 \\
\hline & Total $(\mathrm{N}=34)$ & 12 & \\
\hline
\end{tabular}

Table 4.1 shows mean rank in the use of total metacognitive strategies by the four groups; and highest mean rank is in high-tourism group, followed by low-tourism, high-business English and low-business English respectively in almost all five lessons, except to lesson four that the low-tourism group has the highest mean rank. However, the difference is not much (high-tourism=9.33, low-tourism=9.67). It is also noticeable that in lesson 3 , the mean ranks of both the highand low- tourism groups are almost identical at 9.83 and 9.17 .

Table 4.2 Differences in the total use of metacognitive strategies by four groups of students in five lessons

\begin{tabular}{lllllll}
\hline & Lesson 1 & Lesson 2 & Lesson 3 & Lesson 4 & Lesson 5 & Total \\
\hline Chi-square & 9.59 & 9.42 & 9.18 & 9.66 & 10.04 & 10.00 \\
df & 3 & 3 & 3 & 3 & 3 & 3 \\
Asymp. Sig. & $.02 *$ & $.02 *$ & $.02 *$ & $.02 *$ & $.01 *$ & $.01 *$ \\
$*_{p<.05}$ & & & & &
\end{tabular}

Additionally, Table 4.2 shows the differences in the use of total metacognitive strategies by four groups of students. In general, they significantly and differently reported total metacognitive strategies in five lesson starting from lesson 1 , $\square^{2}(3, N=34)=9.59, p=.02$, lesson $2, \square^{2}(3, N=34)=9.42, p=.02$, lesson $3, \square^{2}(3, N=34)=9.18, p=.02$, lesson 4 , $\square^{2}(3, N=34)=9.66, p=.02$ and lesson $5, \square^{2}(3, N=34)=10.04, p=.01$ respectively. Of five lessons, the highest significant difference is evident in the last lesson at .01 .

The findings of differences on the frequencies of metacognitive strategies across proficiency groups correspond with previous studies (Lui \& Feng, 2011; Cabaysa \& Baetiong, 2010; Ma, 2009). Lui \& Feng (2011) found that high-ability students from Beijing University reported significantly and higher metacognitive strategies in EFL online learning than the low-ability students. Similarly, both the study of Cabaysa \& Baetiong (2010) and Ma (2009) found that the 
advanced-ability students reported greater use of metacognitive strategies than that of the low-ability students. The reason that the high-proficiency group reported more metacognitive strategies may be because high-proficiency students were better aware of the use of their metacognitive strategies, they showed a better self-learning ability and finally, resulted in higher test-achievement as indicated in a study of Lui \& Feng, (2011). Results from Table 4.2 show significant differences in the use of metacognitive strategies among the four groups of students. Comparisons of the total metacognitive strategies among four groups in five lessons were conducted and displayed in the following part.

4.1.2 Group's comparison in total use of individual metacognitive strategies via the InConMedt among four groups of students in five tourism lessons

From the results of Chi-square on the significant and different use of total metacognitive strategies, groups' comparison is further conducted to indicate the differences in the use of these strategies between each pair. The Mann-Whitney $U$ test is then employed to indicate any significant differences among six pairs of group's comparison and results. The abbreviations in the brackets refer to HT as high-tourism group, LT as low-tourism group, HB as high-business English group and LB as for low-business English group. Findings are as follows.

The results from Mann-Whitney U test in groups' comparisons of total metacognitive strategies in 5 lessons show that these pairs of groups used different total metacognitive strategies in some lessons. There is a significant difference at .05 level in the total use of metacognitive strategies in the first pair between high-tourism and low-tourism group in lesson 2(HT=7.05 and $\mathrm{LT}=5.40$ per cent) and lesson 5 (HT=7.65 and $\mathrm{LT}=0.08$ per cent). This is followed by a significant difference at .02 level between high-tourism and high-business English groups in lesson $1(\mathrm{HT}=4.95$ and $\mathrm{HB}=0.26$ per cent $)$ and $5(\mathrm{HT}=7.65$ and $\mathrm{HB}=0.26$ per cent $)$ whereas lesson 2 contains a significant difference between the two groups at .01 level ( $\mathrm{HT}=7.05$ and $\mathrm{HB}=0.16$ per cent).

Concerning a third group between high-tourism and low-business English groups, there is a significance difference in the use of metacognitive strategies at .00 level in lesson 2 ( $\mathrm{HT}=7.05$ and $\mathrm{LB}=0.84$ per cent) and at .04 level in lesson 5 ( $\mathrm{HT}=7.65$ and $\mathrm{LB}=0.08$ per cent). Similarly, a significant difference in the total use of metacognitive strategies is evident between low-tourism and high-business English group at .02 level in lesson 1 and 5 (LT=3.60 and $\mathrm{HB}=0.26$ per cent) whereas lesson 2 contains a significant difference at .01 level ( $\mathrm{LT}=5.40$ and $\mathrm{HB}=0.16$ per cent). All significant differences indicate that these pairs of groups reported different frequencies of metacognitive strategies in these online lessons. There is no significant difference in the total use of metacognitive strategies in the five lessons between lowtourism and low-business English groups and high- and low-business English groups, showing that their use of total metacognitive strategies frequencies did not differ.

The findings of significant different use of total metacognitive strategies between some pairs in some lessons contradict to the study of Swain et al. (2009) on the use of metacognitive strategies in online modality among different proficiency groups and across three different task types. It was found in Swain et al.'s study that there were no significant differences in the use of metacognitive strategies across the three proficiency groups and task types. The reasons that the use of metacognitive strategies in the present study was significantly evident mainly in some lessons, and mostly associated with proficiency levels (high- and low-tourism group, high-tourism and low-business English and lowtourism and high-business English, high-tourism and high-business English), may be due to the relationship between the use of metacognitive strategies and knowledge in lessons' purpose, content and requirement as suggested by Oxford et al. (2004) that benefit of these metacognitive strategies associated with a particular task type. In the current study, task type associates with a particular tourism lesson. Additionally, Swain et al. (2009) reconfirmed Oxford et al. (2004)'s findings that relationship between choice of strategy use and proficiency level relied on participants' characteristics, tasks and context as shown in the present study.

As for the findings of indifferences in the total use of metacognitive in some pairs between the high- and low-business English majored groups, relate to some studies (Hong-Nam \& Leavell, 2006). In the present study, it was found that these two pairs from the same major did not report any significant differences in the total metacognitive strategies, in other words, students from the same major with different proficiency level did not use many different metacognitive strategies for their online learning. In a study of Hong-Nam \& Leavell (2006), metacognitive strategies were favored by both the beginning and intermediate groups in an intensive English program. Following parts are groups' comparisons in three individual metacognitive strategies.

4.1.3 Use of individual metacognitive strategies via the InConMedt among four groups of students in five tourism lessons

This part shows groups' comparison of three individual metacognitive strategies: assessment, goal setting and planning. Mann-Whitney U test was employed to indicate a significant difference among six pairs of group's comparison in each individual strategy.

For assessment strategy used in five lessons, among the six groups, there is a sole significant difference in the use of this strategy at .01 level in lesson 5 between low-tourism and high-business English groups (LT=1.35 and $\mathrm{HB}=0.08$ per cent).This means that only the two groups differently reported assessment strategies in lesson 5 .

As for goal setting strategy, a significant difference at .03 was found between high- and low-tourism groups in lesson 2 $(\mathrm{HT}=2.25$ and $\mathrm{LT}=1.20$ per cent). Similarly, the two groups significantly and differently reported goal setting strategies at .00 level in lesson $5(\mathrm{HT}=2.85$ and $\mathrm{LT}=0.75$ per cent). Additionally, a significant difference is evident at .01 between high-tourism and low-business English groups in lesson 2 ( $\mathrm{HT}=2.25$ per cent) and 5 (HT=2.85 per cent). In other words, goal setting strategies were used mainly by high-tourism group in the two lessons whereas the low-business English group did not report any of these strategies in the rest four lessons. 
Finally, results of planning strategy are displayed. Among six pairs to compare, a significant difference was at .02 level in the use of planning strategies found between high- and low-tourism groups in lesson 5 (HT=2.85 and LT=1.50 per cent). High-tourism and high-business English groups also significantly and differently reported their planning strategies at .01 level in lesson 1 ( $\mathrm{HT}=1.95$ and $\mathrm{HB}=0.12$ per cent). Similarly, a significant difference is evident between low-tourism and high-business English groups at .01 level in lesson 1 and 5 at the same percentages (LT=1.50 and $\mathrm{HB}=0.12$ per cent). In other words, these pairs of groups differently reported their planning strategies in these lessons.

The findings of significant differences in some individual metacognitive strategies in some pairs and particular lesson contradict to a study of Swain et al. (2009) that did not find any statistical significant difference in the use of submetacognitive strategies across proficiency levels and task types. However, a wider range of sub-metacognitive strategies was reported in an integrated task than in the independent one. The reason for different use of individual metacognitive strategies in some lessons and in some pairs in the present study may be due to the realization on the use of metacognitive strategies and knowing specific features of lesson, i.e. objective, English language use, content and requirement which may support the high-proficiency group to use more metacognitive strategies than the lowproficiency group in some lessons namely 1, 2 and 5. Previous study from Lam (2010) emphasized on benefit of metacognitive strategy associated with specific tasks. It was also suggested from this study that matching strategy choice with task-type as pre-existing task-specific strategies were worth it and tended to be activated more by metacognitive strategies than those that were non-task specific. By directing learners' attentions to their own strategies, particularly the ones that were found to be affective in the study, would help students to learn the language effectively as presented in the treatment group.

Moreover, it is evident in this study that lesson 5 (giving polite suggestion to the tourists) has the most differently reported individual metacognitive strategies across proficiency groups and majors which may due to specific characteristic of particular English language use and the amount of specific tourism content knowledge required for this lesson. In this lesson apart from English language knowledge, students were faced with different situations that they may encounter with tourists. They needed to use both language and tourism knowledge to be able to give polite suggestions to the tourists. In doing this, they may need to assess the objective of the lesson, set a goal and plan their responses. The high-proficiency group may know better how to use these metacognitive strategies in this lesson as claimed by the study of Lui and Feng (2011) that knowing the use of metacognitive strategies would facilitate learners to learn the language effectively. Followings are qualitative content analysis from the verbal reports in the stimulated recall interview session.

4.2 Content analysis from the verbal reports from four groups of student on the total and individual use of metacognitive strategies in five lessons.

This section shows the content analysis from verbal reports of 34 students on their use of metacognitive strategies in five lessons from the InConMedt. The aim is to present the insights how students from each group employ their metacognitive strategies in the online lessons.

Students' identification is coded by both letter and number. The first letter refers to their proficiency level, ' $\mathrm{H}$ ' representing 'the high-proficiency group', and letter ' $L$ ', representing 'the low-proficiency group'. The second letter refers to their major of study, ' $\mathrm{T}$ ' representing 'tourism industry students' and ' $\mathrm{B}$ ' representing 'business English students'. The third letter, ' $L$ ' indicates lesson in the InconMedt. The first number refers to the number of the students and the second number is the number of the lesson. The asterisk symbol, '*', indicates emerging strategies that are not in metacognitive strategies. The following data is presented by the order of the lesson. The categorization of the strategies in this study is adapted from Douglas (2000, p.78-79) and O'Malley and Chamot (1990, p.44). Only the strategies that are reported by the students are presented in this study. They are assessment, goal setting and planning. Followings are details from the individual metacognitive strategies.

Assessment strategy is used by the student to assess what is needed, what one has to work with and how well one has done to achieve the tourism communicative goal and objective of the lesson.

In 5 lessons high- and low-tourism groups assessed how well they have done and thought of what they should improve for their speaking performances. Whereas high- and low-business English students were mainly assessed on how well they have done in lesson 1. It was evident that only the high-tourism group thought of what was needed to improve their speaking performance in lesson 1 and 2. Additionally, low-proficiency students in both tourism and business English majors did that and also compared their performances with others in lesson1. What was evident in lesson 3 was that high-tourism group compared their learning with the actual performance. Low-business group also reported on what they have achieved only in lesson 4. Finally, it was notable in lesson 5 that low-business English students mainly assessed how well they have done in this lesson. Following are some examples.

HT8L1: I assessed myself by playing back the recorded audio file and thought that I should have improved on my pronunciation.

LT2L1: I assessed myself by playing back the recorded audio file and I needed to improve on the fluency and pronunciation.

LT1L2: I assessed my performance, but I could slowly memorize all the content after several times. I couldn't pronounce some words. I needed to try harder.

HT5L2: I assessed my script and found minor revisions about sentence structures because I used too many repeated words such as next. 
HT11L3: I assessed my performance from my own perspective that it should be better. There was so much information and I did not pay full attention to it. I should have review and done my homework, practiced reading and presenting before attending the class.

HT5L3: I assessed how well I spoke in front of the mirror comparing to the actual classroom presentation, and assessed whether which one should be better.

LT8L4: I found that after my presentation I could memorize the Buddha postures.

HT5L5: I assessed my listening skills, especially tourist' enquiries and the way to respond to them. For example, when my lecturer asked the questions about tourist' enquiries in English and I needed to respond in English. I assessed how well I could respond to her questions.

LT15L5: I still did not do well in the in class presentation because I did not put lots of effort on my work and I did not have enough time to practice both the presentation and pronunciation from many activities that I had.

HB2L5: I thought that sometimes I can speak well, but sometimes not. I thought that the actual speaking was different from taking notes. It was not as clear as the written language.

LB1L5: I should have done better.

LB2L5: I was not satisfied with my performance.

A goal setting strategy is employed by the students to identify the contents and English language use in the lessons and decide what one should do to achieve the objectives of the lesson.

For 5 lessons, most of the high-proficiency students identified the contents and English language use in the lesson and also decided what to do to achieve the objective of the lesson. Some of the low-tourism did the same thing as the high students in lesson 1. However, low-tourism and both high-and low-business English students mainly decided on what to do to achieve the lesson's objective in lesson 1 whereas only the low-tourism group mainly did that in lesson 3 . It was evident in lesson 2 that the high-proficiency business English students mainly identified the content to reach the objective of this lesson. In lesson 4, the majority of the low-tourism mostly either decided on what to do to achieve their goal, particularly to understand the meaning and major characteristics of the Buddha images or decided on the English language use to achieve their goal. Finally, majority of the low-proficiency tourism students mainly decided on what to do to achieve their goal in lesson 5.

HT2L1: I thought about the lesson and told myself that I should understand the vocabulary and expressions to welcome the tourists.

LT4L1: I set up my goals that I needed to understand the content and try to apply them into real life context.

HB2L1: I thought of the content to speak.

LB1L1: I needed to know the content to speak.

HB1L2: I tried to find related content to explain to the tourists.

HT11L3: I did set my goals to present tour itinerary in sequence as follows:

1. I needed to know about history of the Emerald Buddha temple and the Grand Palace as much as I can.

2. I should be able to explain about the attractions as best as I can.

3. I needed to understand English sentences explaining these attractions for the tourist.

LT5L3: I thought that I needed to collect and understand all the content that my lecturer taught me in class.

LT9L4: I should know about the technical terms to present characteristics of the Buddha images in script writing or describing to the tourists.

LT2L5: I set goal that I put all my attention in class and if I try hard enough I will be able to do the task.

Planning strategy is called upon to make decisions about how to use the existing English language knowledge and tourism related content knowledge to achieve the objective of the lesson and communicative goal in tourism context.

For lesson 1, the majority of the high-proficiency tourism groups mainly planned their speaking by deciding on how to use the tourism related knowledge to welcome the tourist, whereas the low-proficiency group mainly decided on how to use vocabulary in their speaking in lesson 1 and 2. It is evident in high-business English students that they decided on how to use both the English language and tourism content knowledge in their speaking while each of the low students would use each procedure in their speaking in lesson 1 and 2. For lesson 3, both the high- and low-proficiency tourism students, and low-business English students mainly planned their speaking by deciding on how to use both the English language, particularly on their vocabulary and pronunciation. Some of the high-proficiency tourism groups also planned their language and tourism content knowledge in their speaking. However, the high-business English students mainly planned their content to speak.

For lesson 4, almost all of the students in four groups mainly planned their lesson by deciding on how to work with their vocabulary and pronunciation to present the Buddha images at the Emerald Buddha Temple in this lesson and give polite suggestions to the tourists in lesson 5. It was also evident in the high-proficiency tourism students that they also planned on how to use sentence structures in lesson 4 and 5. Some examples are as follows.

HB1L1: I set up the time to speak to the tourists. I put the expressions in the right order. I gathered all my thoughts and information from short notes.

HT1L1: I planned to find information from the Internet. 
LB1L1: I planned to practice with my friend in class.

LT3L1: I found unknown vocabulary from different sources.

HB2L2: I planned the content to speak.

LB1L2: I planned to practice speaking using English with my friend in class.

LT4L2: I planned by finding vocabulary before class to understand the content for my presentation. I use what I know from my field trip.

HT11L3: After I got all vocabulary, sentence structure and how to write tour itinerary, my group and I started to plan our lesson. I started from selecting the attraction which was Bangkok to Nakhon Pathom. After finishing the schedule, I used all sequential connectors such as first, next, then, after that, and finally in our script. We then practice our script for 10 minutes before the presentation.

HT8L3: I planned by searching the contents from the documents before attending the class. I translated all unknown vocabulary and sometimes I practiced pronouncing them before my presentation.

LT9L3: I was assigned to present Ratchaburana and Chaiwattanaram Temple in Ayutthaya and I planned by finding information in both Thai and English. I also prepared all vocabulary.

HB1L3: I set up the plan to speak in a chronological order about the content of the attractions.

LB1L3: I prepared reading my script before my presentation in class.

HT11L4: I planned to find all the technical terms and sentence construction, study them and the content until I understood and finally wrote the script.

LT15L4: I planned my lesson by preparing the information before class and finding all unknown vocabulary. I also planned to practice my pronunciation.

HB2L4: I planned the content to speak to explain about the postures of Buddha images.

HT5L4: I planned to find all the technical terms in presenting Buddha images, lay out all the sentence structures for my script, and practice pronouncing words correctly. If I was not sure about any words I used dictionary.

HT1L5: I planned to memorize vocabulary, translate all of them for the content and information about the attractions so that I would be able to give suggestions to the tourists.

LT15L5: I planned my lesson by preparing the information before class and finding all unknown vocabulary. I also planned to practice my pronunciation when I had time.

HB2L5: I decided and focused on using the knowledge from the previous course. Then I decided on the structures and words to use to give suggestions to the tourists. I also thought of particular expression to respond to tourists.

LB2L5: I planned to speak with my friend in class. I planned to find some vocabulary.

Apart from metacognitive strategies, students also employed other strategies in their lesson. These strategies are in cognitive strategies: *memorizing information and *activating background knowledge. These two strategies are mainly reported by the high-proficiency tourism students in lesson 1,3 and 5. Followings are some examples.

Memorizing information means students memorized information and use them in the lesson. Students memorized sentence in lesson 1 to greet the tourists whereas they would memorize the important situations in lesson 5 to give polite suggestions to the tourists at the tourist attractions. Examples are as follows.

HT8L5: By memorizing an important event at the actual site, I would be able to tell all the stories and true information to the tourists as has been told from generation to generation. It was like our heritage.

Activating background knowledge means students recalled the past content from their previous experience and knowledge. Students recalled their content knowledge from their previous experience in lesson 1 and 3 from their field trip and from their work experience. Examples are as follows.

HT11L3: For presenting tour itinerary lesson, I had limited time to create a 1-day trip tour itinerary and simulate all the scenarios and presenting it to the tourists. I did use strategy by calling back my previous experience and background knowledge that I had during my past time job as a tour guide assistant.

\section{Conclusion}

This study aimed to compare total use of metacognitive strategies by four groups of university students from different majors in five different online tourism lessons and, compare their use of individual metacognitive strategies. The findings showed that students from different proficiency levels and majors significantly and differently reported total metacognitive strategies in some lessons. The significant difference was evident in the use of goal setting and planning strategies in some groups in lesson 1,2 and 5. The findings from the present study provide more insights into the use of metacognitive strategies via online learning modality that varies in proficiency levels which agree with the findings from previous study (Hong-Nam\& Leavell, 2006; Cabaysa\& Baetiong, 2010), including fields of study of learners, and specific features of online LSP lessons. As stated by Oxford (2004) and Swain et al. (2009) that benefits and use of types of metacognitive strategies depend on learners' characteristics, tasks and context as found in the findings of the present study. It is also interesting to see how students from different proficiency levels and majors make use of their metacognitive strategies to learn from particular lesson in online modality. Findings from a recent study of Lui \& Feng 
(2011) and the present study thus indicated that students who were aware of metacognitive strategies in their learning in line with knowing specific features of English language use in LSP setting would have better learning as seen in the high-proficiency groups. Metacognitive strategies are found to be effective and favored by these students and they way they utilized metacognitive strategies in their learning in particular lesson should be taken into consideration in teaching methodology of LSP courses. The primary goal is to facilitate all of the students, particularly the low-proficiency group to learn the language effectively, and finally support them to reach their potential of their learning with this innovative learning tool.

\section{Suggestions for future research}

This study focuses mainly on metacognitive strategies used in speaking performances; emerging strategies that occurs in this study should be investigated for future research. Additionally, students' characteristics, particularly other fields of study should be included to see how students from other majors utilize their metacognitive strategies in their language learning via an online lesson. Considering the number of the sample in this study, especially from some majors, there should be a plan to check for the number of students registered in the course. This includes the number of dropout rate in the course that should be taken into consideration before conducting the study.

\section{References}

Barhoumi, C., \& Hamza kabli, T.B.H. (2013).The improvement of lifelong learning in Saudi Arabian University from individual learning to social constructivist E-learning environment based new education technologies. European Scientific Journal, 9(13),78-98.

Cabaysa, C.C. and Baetiong, L.R. (2010). Language learning strategies of students at different levels of speaking proficiency. Education Quarterly, 68(1),16-35.

Churcher, K.M.A, Downs, E., \& Tewksbury, D. (2014). Friending Vygotsky: A social constructivist pedagogy of knowledge building through classroom social media use. The Journal of Effective Teaching, 14(1), 33-50.

Douglas, D. (2000). Assessing languages for specific purposes. Cambridge: Cambridge University Press.

Fulcher, G. (2003). Interface design in computer-based language testing. Language Testing, 20(4), 384-408.

Hon-Nam, K. \& Leavell, A. (2006). Language learning strategy use of ESL students in an intensive English learning context. System, 34, 399-415.

Islam, J. Md. and Aktar, T. (2011). Metacognitive language-learning strategies and language-learning motivation: A study on Bangla-speaking undergraduate EFL learners. Outlooks: VUB,l(1), 130-148.

Ismaili, M. (2014). Integrating CALL into the EFL classroom. The Journal of Teaching English for Specific and Academic Purpose, 2(4), 697-702.

Lam, W.Y.K. (2009). Examining the effects of metacognitive strategy instruction on ESL group discussions: A synthesis of approaches. Language Teaching Research,13(2), 129-150. doi: 10.1177/1362168809103445

Lam, W.Y.K. (2010). Implementing communication strategy instruction in the ESL oral classroom: What do lowproficiency learners tell us? TESL Canada Journal, 27( 2), 11-30.

Leavell, A.G. (2006). Language learning strategy use of ESL students in an intensive English learning context. System, 34(3), 399-415. doi:10.1016/j.system.2006.02.002

Liu, Y., \& Feng H. (2011). An empirical study on the relationship between metacognitive strategies and onlinelearning behavior \& test achievements. Journal of Language Teaching and Research,2(1),183-187. [Online] Available: http://dx.doi.org/11.5679/elt.v7n6g7h13 (May 22, 2015)

Luksaneeyanawin, S. (2008). The paradigm shift in language learning: Toward autonomy of learning. Paper presented at ThaiPOD conference. Bangkok:Thailand.

Ma, T. (2009). An empirical study on the comparison between strategies on oral English classes and writing English classes. English Language Teaching,2(2), 39-45.

McMahon, M. (1997). Social constructivism and the world wide web: A paradigm for learning. Paper presented at the ASCILTE conference. Perth:Austria.

Mitchell, H., \& Myles, F. (1988). Second language learning theories. London: Arnold.

NakhonRatchasimaRajabhat University. (2008). Curriculum for bachelor of arts in English. Nakhon Ratchasima: Nakhon Ratchasima Rajabhat University.

NakhonRatchasimaRajabhat University. (2008). Curriculum for bachelor of arts in tourism industry. NakhonRatchasima: Nakhon Ratchasima Rajabhat University.

O'Malley, J.M. and Chamot, A.U. (1990). Learning strategies in second language acquisition. Cambridge: Cambridge University Press.

Oxford, R., Cho, Y., Leung, S. and Kim, H-J. (2004). Effect of the presence and difficulty of task on strategy use: An exploratory study. International Review of Applied Linguistics in Language Teaching, 42(1), 1-47. DOI: 10.1515/iral.2004.001

Phaiboonnugulkij, M. and Prapphal, K. (2011). Why should the web-based achievement tests in English for tourism be implemented? ABAC Journal, 3(1),36-52. 
Phaiboonnugulkij, M. and Prapphal, K. (2013). Online speaking strategy assessment for improving speaking ability in the area of language for specific purposes: The case of tourism. English Language Teaching, 6(9), 19-29.

Phaiboonnugulkij, M. (2015). Insights into InConMedt: A practical guideline. Pertanika Journal of Social Sciences and Humanities (JSSH), 23(4), 1179 - 1192.

Phaiboonnugulkij, M. (in press). Comparative analysis of metacognitive strategies used in the internet-integrated test to enhance English speaking ability in Thai tourism context. International Journal of Economic Policy in Emerging Economies.

Schcolnik, M., Kol, S., \& Abarbanel, J. (2006).Constructivism in theory and practice. English Teaching Forum, 4,12 20 .

Swain, M., Huang, L., Barkaoui, K., Brooks, L. and Lapkin, S. (2009). Educational testing service (ETS)', The Speaking Section of the TOEFL iBT (SSTiBT): Test-takers' Reported Strategic Behaviors, TOEFL iBT Research Report No. 10 [Online] Available: http://www.ets.org/Media/Research/pdf/RR-09-30.pdf (February, 20 2014).

Tarnopolsky, O. (2013). Developing ESP students English speaking, reading, listening and writing skills in Internetassisted project work. The Journal of Teaching English for Specific and Academic Purpose, 1(1),11-20.

The Authority of World Travel and Tourism. (2015). 2015 Annual research: Key facts. [Online] Available: http://www.wttc.org/-/media/files/reports/economic\%20impact\%20research/countries\%202015

/thailand2015.pdf (October, 28 2015)

Vygotsky, L. S. (1978). Mind in society. The development of higher psychological processes. M. Cole, V. John-Steiner, S. Scribner, \& E. Souberman (Eds.). Cambridge, MA: Harvard University Press.

Vygotsky, L.S. (1987). Thinking and speech. In R.W. Rieber \& A.S. Carton (Eds.) The collected works of L.S. Vygotsky, Vol. 1, Problems of general psychology (pp.39-285). New York: Plenum Press.

Wen, Qiufang \& Wang, J. (2006). Learning strategies analysis system. [Online] Available: http://www.jyw.cn/Index.html (October, 28 2015)

Wilson, K. (1999). Note-taking in academic writing process of non-native speaker students: Is it important as a process or a product? Journal of College Reading and Learning, 29(2), 166-179.

Winke, P. (2014). Review of open English. Language Learning \&Technology, 18(2),75-84. 